\title{
ANALYSIS OF ACOUSTIC PROPAGATION OF AUTOMOTIVE COOLER DURING RUN UP AND RUN DOWN
}

\author{
Wojciech PALUCH, Maciej KLACZYŃSKI \\ AGH University of Science and Technology, Faculty of Mechanical Engineering and Robotics, \\ Department of Mechanics and Vibroacoustics, A. Mickiewicza 30, 30-059 Kraków, Poland, \\ e-mail: wpaluch@agh.edu.pl, maciej.klaczynski@agh.edu.pl
}

\begin{abstract}
The modern automotive industry invests more and more in electric drive technology. As a result, new challenges arise in terms of vibroacoustic optimization of the car interior. Components that were once masked by the internal combustion engine are starting to dominate the interior of vehicles. There is therefore a great need for noise reduction. For this purpose, a number of methods of its reduction are used, i.e. component optimization (source), use of active noise reduction systems or passive soundproofing materials. In order to perform the abovementioned noise reduction measures, appropriate measurements and signal analysis should be carried out. This presentation aims to present the measurement of an automotive air cooler in transient states on the stand. Measurements were made using a 3D intensity probe based on the direct measurement of the acoustic particle velocity, in 3 planes in front of the cooler. Then, order tracking analysis was performed for the run-up and coast-down. The results in the form of selected orders of intensity and acoustic particle velocity were compared with classical results made with the use of a microphone at the same measurement points locations.
\end{abstract}

Keywords: automotive, electric vehicle noise, interior noise, vibroacoustics, sound intensity measurements

\section{ANALIZA PROPAGACJI AKUSTYCZNEJ CHŁODNICY SAMOCHODOWEJ W CZASIE ROZBIEGU I WYBIEGU}

Streszczenie

Współczesny przemysł motoryzacyjny inwestuje coraz bardziej w technologię napędu elektrycznego. W związku z tym pojawiają się nowe wyzwania w zakresie optymalizacji wibroakustycznej wnętrza samochodu. Komponenty, które kiedyś były maskowane przez silnik spalinowy zaczynają dominować we wnętrzu pojazdów. Istnieje zatem duża potrzeba redukcji hałasu. W tym celu stosuje się szereg metod jego redukcji, tj. optymalizacja komponentu (źródła) zastosowanie aktywnych systemów redukcji hałasu lub pasywnych materiałów wygłuszających. Aby dokonać wspomnianych zabiegów redukujących hałas, należy przeprowadzić stosowne pomiary oraz analizę sygnałów. Niniejsza prezentacja ma na celu przedstawienie pomiaru chłodnicy samochodowej w stanach nieustalonych na stanowisku. Pomiarów dokonano przy użyciu sondy natężeniowej 3D bazującej na bezpośrednim pomiarze prędkości akustycznej cząsteczek, w 3 płaszczyznach przed chłodnicą. Następnie wykonano analizę rzędów (order tracking) dla rozbiegu oraz wybiegu. Wyniki w formie wybranych rzędów (orderów) natężeń oraz prędkości akustycznej cząstek zestawiono $\mathrm{z}$ klasycznymi wynikami wykonanymi przy użyciu mikrofonu $\mathrm{w}$ tych samych punktach pomiarowych.

Słowa kluczowe: motoryzacja, hałas pojazdów elektrycznych, hałas wewnętrzny, wibroakustyka, pomiary natężenia dźwięku

\section{INTRODUCTION}

The analysis of acoustic phenomena inside the car with an indication of their significance and location is a complex task. A typical measurement technique for the vibroacoustics of the car interior is the measurement of sound pressure using a microphone. Typically it is placed at the driver's or passenger's ears. In the acoustics of the car interior, which are very complex $[6,8,12,13,14,15,17]$, the information provided by the sound pressure is often insufficient. The main reason for this is the scalar dimension of sound pressure. In order to obtain information about the significance and direction, measurements based on vector values such as acoustic intensity and acoustic velocity of particles $[1,2,5,9,16]$ should be used.

Among the best known and widespread vector methods, one should mention $[7,15]$ :

- measurements using intensity probes based on the 1D and 3D acoustic pressure, so-called p-p ,

- measurements using intensity probes based on acoustic pressure and direct measurement of the acoustic velocity of particles $1 \mathrm{D}$ and $3 \mathrm{D}$, socalled $\mathrm{p}-\mathrm{u}$,

- measurements using laser anemometry. 
In addition to the above-mentioned methods, there are a number of extensive measurement and analytical techniques for the analysis of acoustic sources inside the car, such as transfer path analysis (TPA) [10], acoustic holography using spherical microphone arrays [11], multi-layer matrices for measuring interior fragments [5] or scanning methods [2, 4]. The last method that can be mentioned is the multi-sensor intensity analysis [3]. All the above-mentioned methods have their strengths, but also very serious limitations. When considering acoustic phenomena inside the car, one should take into account their occurrence stationary or operational conditions, availability of measuring equipment, financial aspect of measurements. Taking into account the abovementioned criteria, the authors assumed that the best solution that allows to meet most of the assumptions are three-dimensional $\mathrm{p}-\mathrm{u}$ intensity probes.

The positives of the above measuring system include:

- size (the 3D probe has the dimensions of a $1 / 2$ " microphone, including 3 orthogonal sensors of particle acoustic velocity and a microphone,

- availability (the sensor manufacturer is a Polish company located in Rybnik, more: https://weles-

acoustics.com/en/products/WA301/)

- possibility of measurement in stationary and operational conditions - small size, simple and quick installation, possibility of measuring stationary signals and pulses

- price of sensors, allowing the use of more than 1 probe.

A slight disadvantage is the fact that the sensor in question has a non-linear characteristic (Fig. 1) and a frequency range of up to $10 \mathrm{kHz}$.

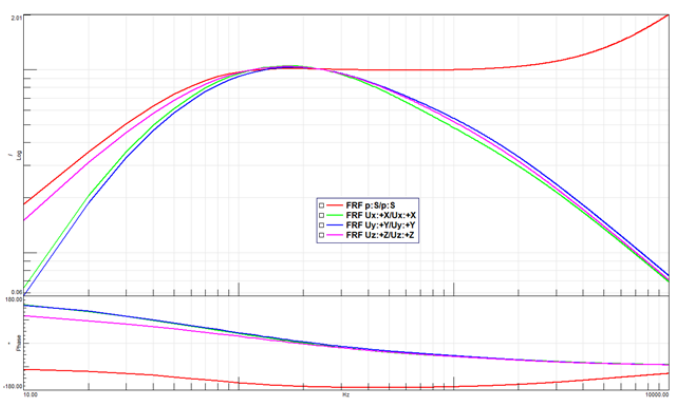

Fig. 1. Nonlinear characteristics of the $\mathrm{p}$-u probe sensors

However, for measurements inside the car, the $10 \mathrm{kHz}$ frequency range is more than enough. On the other hand, the non-linearity of the transducer is compensated by corrections provided by the manufacturer. An additional assumption is the fact that in their research the authors focus only on the noises transmitted through the structure and not by air. In this case, aerodynamic noise, ventilation outlets or exhaust streams will not be the subject of the team's work.
By selecting the $3 \mathrm{D}$ p-u probe as a measuring tool, we can make the following research hypotheses:

- the use of more than 1 probe will allow to determine the location and significance of the noise source,

- using the dependence that in a very close field the acoustic velocity of particles is approximately equal to the velocity of the vibrating surface, it will be possible to determine the surfaces / panels of the interior that emit noise,

- phase synchronization of signals with vibration of components or rotational speeds will allow for better separation of the analyzed source,

- the inability to determine the direct source, but its reflection is also important information from the point of view of the analyzed component, (component manufacturers have no influence on the geometry of the vehicle interior)

The method enabling the verification of the theses will be based on the implementation of software for processing the collected data from one or more intensity probes and specific processing of the collected signals. Certainly, it will be bandpass filtering of the signal, with particular emphasis on filters with zero phase distortion. Specifically, this type will be necessary when using particle sound velocity signals for source localization (methods like triangulation, principal component analysis (PCA), etc.). The next analyzes that I will use will be related to rotating elements such as all kinds of electric motors (wipers, electric window lifters, main electric or internal combustion engine and other rotating elements). These will certainly be order tracking, Kalman filter as time domain analysis, and perhaps angle domain analysis. Spectrograms from selected portions of data will also be necessary for general analysis.

In the tests of the run-up and run-down of the passenger car radiator fan, which was a pilot of the discussed subject, the p-u type 3D intensity probes (Fig. 2), with 3 orthogonal particle acoustic velocity sensors and a microphone, were used to collect relevant data. Each of the speed sensors has a cardioid characteristic (in the shape of the number 8 ), which ensures the directivity of the measurement (Fig. 3).

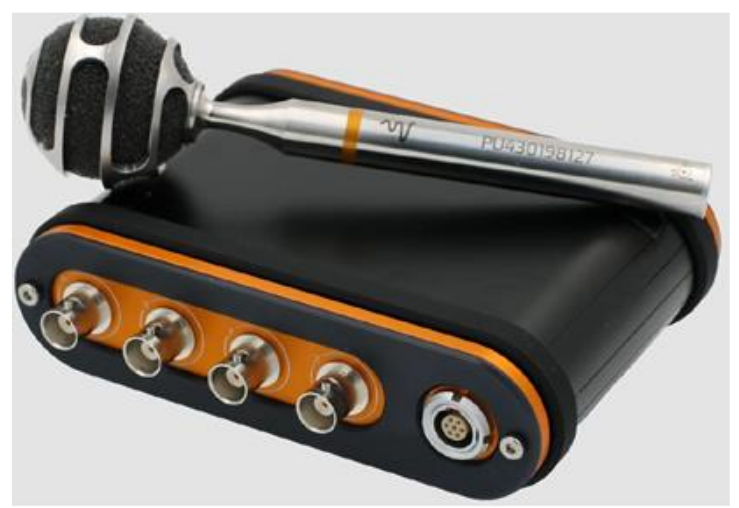

Fig. 2. 3D intensity probe WA301 with conditioner 


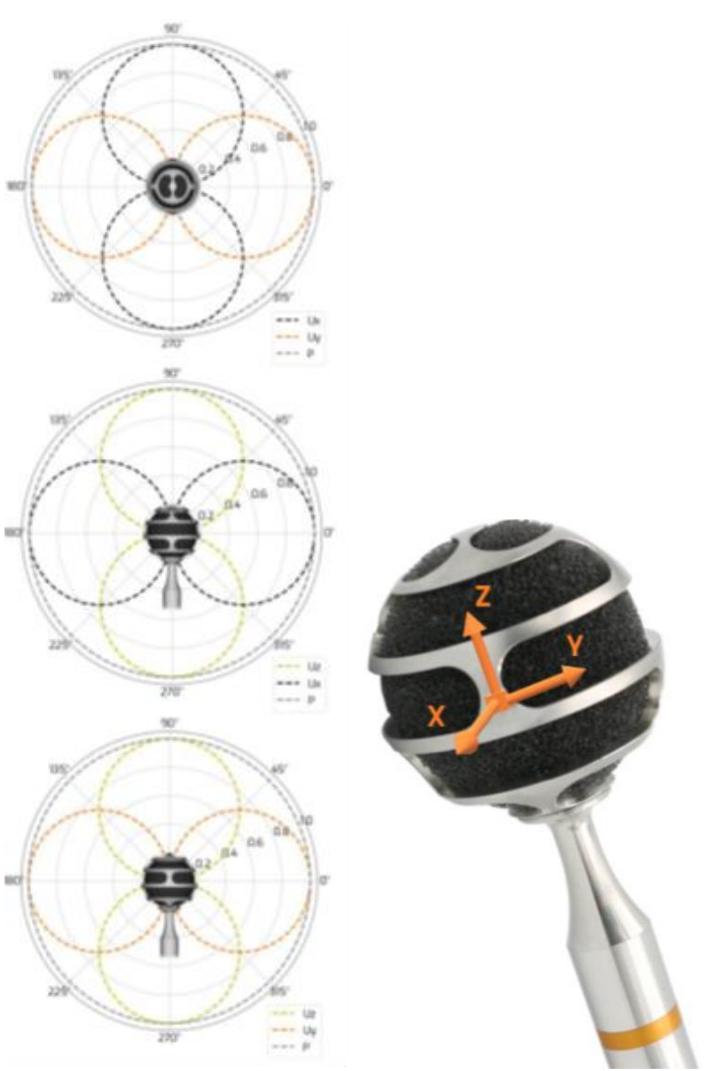

Fig. 3. Directional characteristics of individual particle velocity sensors and their interrelationships.

\section{MEASURMENTS}

In this pilot study, measurements were made of the automotive component, which is an air cooler. The purpose of the measurements and analyzes was to verify the measurement capabilities of 3D intensity probes in non-stationary measurements. This type of issue has not been widely discussed in literature or industry documents so far. The vast majority of research based on measurements of the physical field, which is the vector field of sound intensity, concerns stationary vibroacoustic phenomena. In the discussed case, it was a fan runup and overrun along with a passenger car radiator. The object was measured in two acoustic fields (Fig. 4a and Fig 4b): in an anechoic chamber and in a scattered field, i.e. a laboratory room with many complex reflecting surfaces. In both cases, the cooler was elastically suspended on rubber elements, which were to prevent the measured object from falling into resonance within the interesting measuring range.

During the measurements, 1D sound intensity probe type WA101 WelesAcoustics, 3D sound intensity probe type WA301 WelesAcoustics, a tachometer to measure the rotational speed and an accelerometer as a phase reference mounted on the radiator motor housing were used.

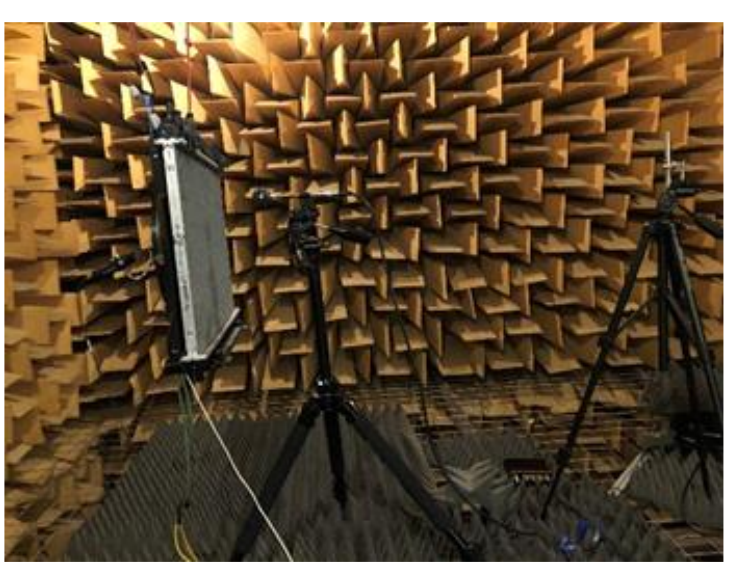

Fig. 4a. Device under test resiliently suspended in an anechoic chamber

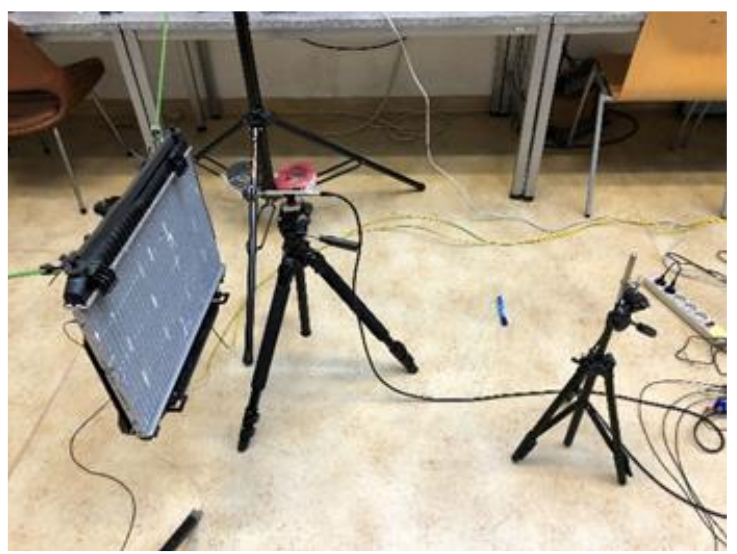

Fig. 4b. Device under test resiliently suspended in an reverberation field

All sensors and additional reference sensors, such as accelerometers and tachometer, were connected directly to the Siemens Simcenter SCADAS dynamic analyzer with the Simcenter TestLab software, which enables synchronous data recording with full acoustic bandwidth $20 \mathrm{~Hz}-$ $20 \mathrm{kHz}$. Matlab software was used for animation, visualization of directions, spatial analysis and validation method.

There were 3 measuring surfaces, each with 8 points and placed in relation to the measuring object at the following distances: 15,25 , and $45 \mathrm{~cm}$. (Fig. 5).

A complete record of the cooler run-up and run down was made at each point. 24 partial measurements were made. The analysis was performed in the domain of rotational speed for all measured values (order tracking) with the following parameters: number of orders 32, resolution 0.125 order, step in revolutions 15, phase reference: vibration sensor. 


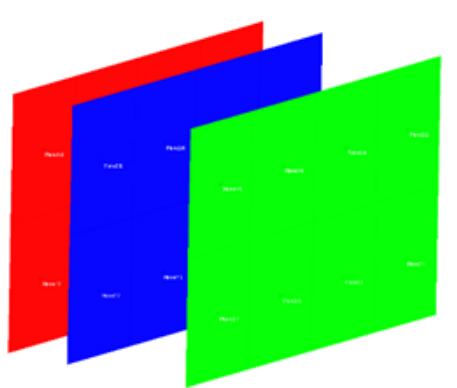

Fig. 5. Measurement surfaces view

Below are examples of the charts of orders 1,7 and 14 of the acoustic velocity of the particles in the direction normal to the surface of the cooler (Fig. $6 a-6 d$ ) on the plane 1, i.e. at a distance of 15 $\mathrm{cm}$ from the cooler. The selected orders were chosen according to the rotational speed (order 1), the multiplicity of the blades (order 7), 2x the multiple of the blades (order 14), $3 x$ the multiple of the blades (order 21), the $4 x$ the multiple of the blades (order 28). Additionally $16^{\text {th }}$ order is presented related to magnetic forces.
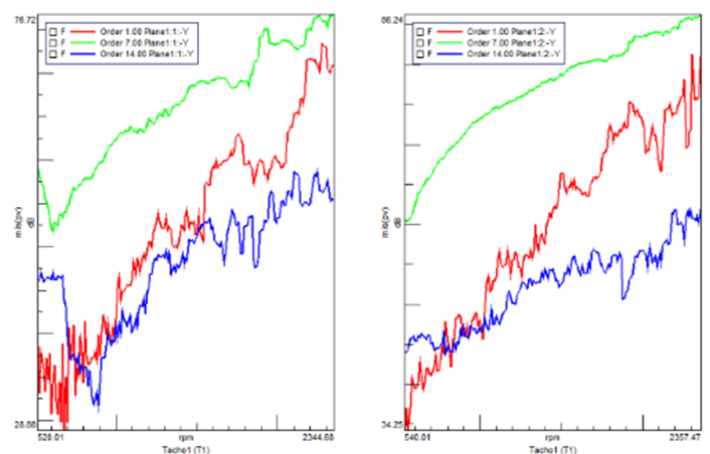

Fig. 6a. List of orders 1, 7 and 14 for each measuring point on area 1 , i.e. $0.15 \mathrm{~m}$ from the automotive cooler
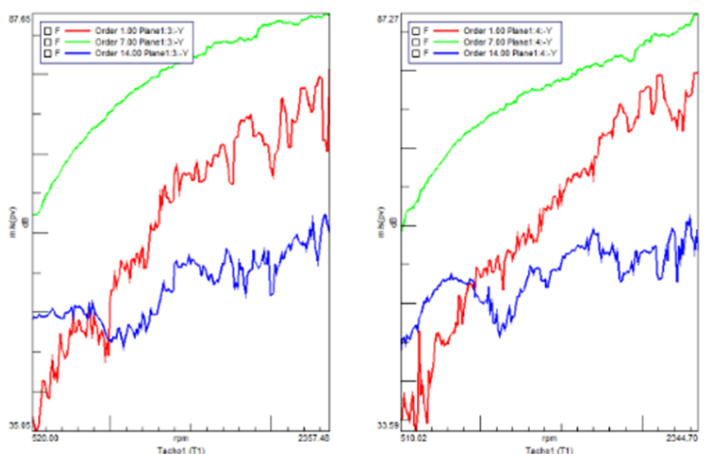

Fig. 7b. List of orders 1,7 and 14 for each measuring point on area 1, i.e. $0.15 \mathrm{~m}$ from the automotive cooler
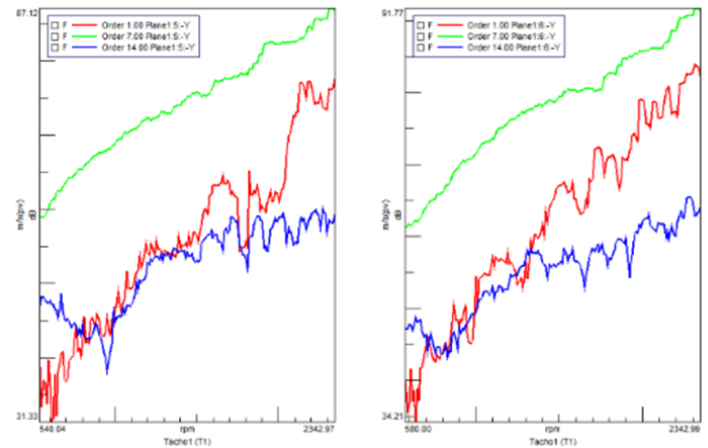

Fig. 8c. List of orders 1,7 and 14 for each measuring point on area 1, i.e. $0.15 \mathrm{~m}$ from the automotive cooler
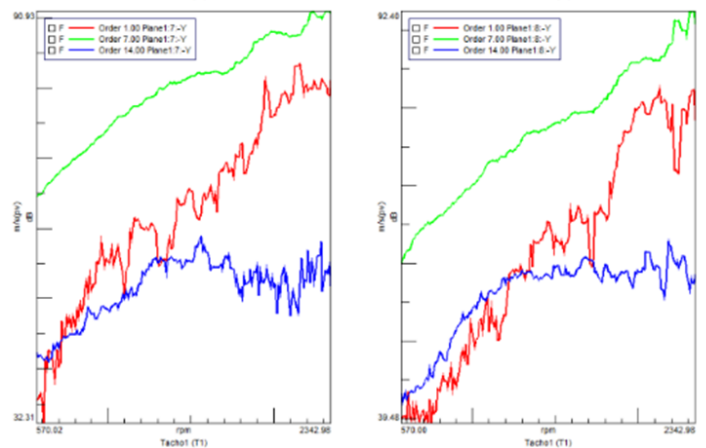

Fig. 9d. List of orders 1, 7 and 14 for each measuring point on area 1 , i.e. $0.15 \mathrm{~m}$ from the automotive cooler

From the calculated orders, animations were made and presented in a decibel scale (Fig. 7a-7f).

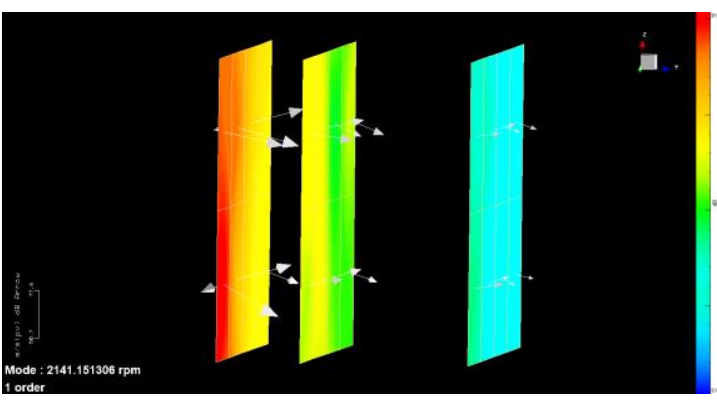

Fig. 10a. Examples of particle acoustic velocity distributions for $1^{\text {st }}$ order (rotational speed).

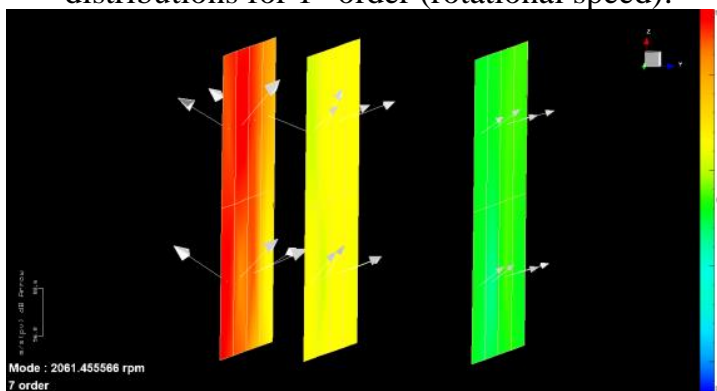

Fig. 11b. Examples of particle acoustic velocity distributions for $7^{\text {th }}$ order. 


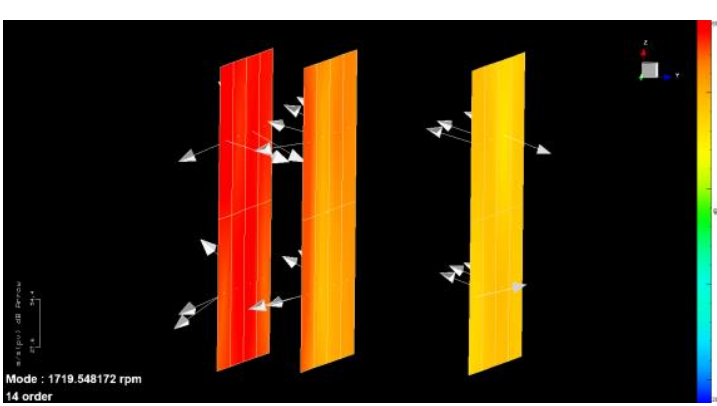

Fig. 12c. Examples of particle acoustic velocity distributions for $14^{\text {th }}$ order.

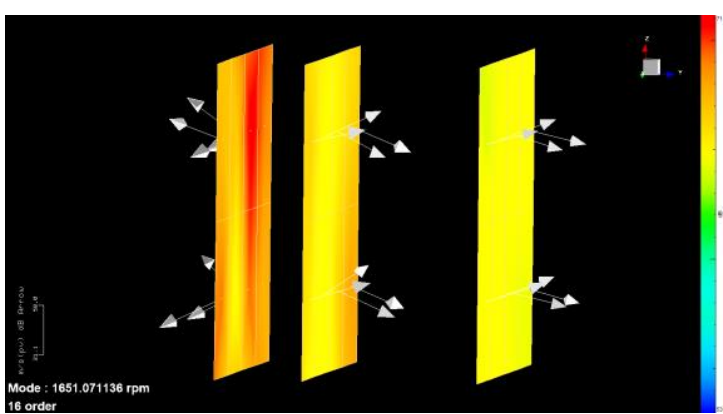

Fig. 13d. Examples of particle acoustic velocity for $16^{\text {th }}$ order.

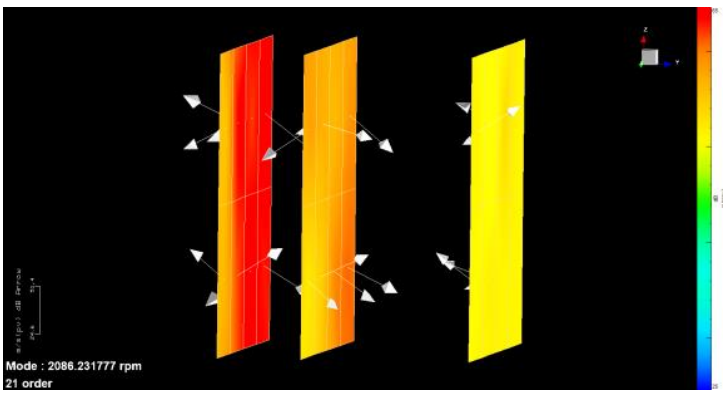

Fig. 14e. Examples of particle acoustic velocity distributions $21^{\text {st }}$ order.

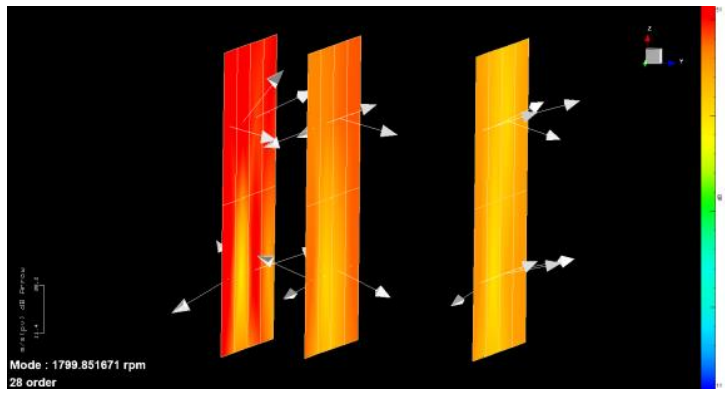

Fig. 15f. Examples of particle acoustic velocity distributions depending on the plane and measuring point.
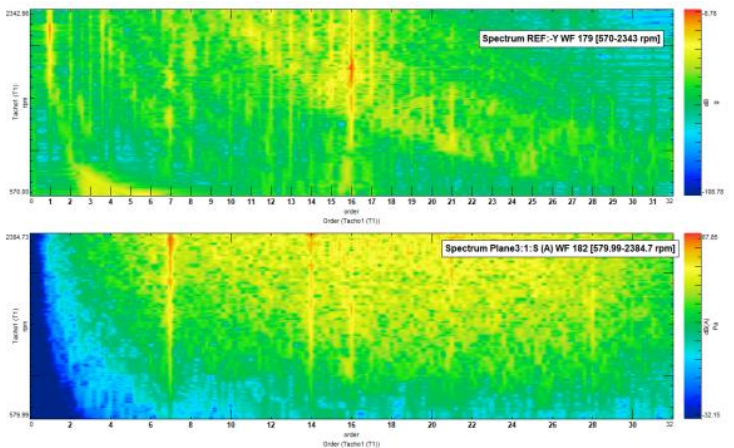

Fig. 8. Order maps of acceleration on a shroud of cooler and microphone from $3^{\text {rd }}$ (the furthest plane).

The presented partial results from the radiator run-up present the possibilities of locating and identifying sources of non-stationary noise with the use of a 3D intensity probe. Phase synchronization made it possible to "glue" individual measurements into one synchronous image, despite the nonstationary nature of the cooler operation. The use of multiple sensors will allow the development of the source directivity analysis system and the precision of its determination.

\section{SUMMARY}

- Analysis of non-stationary phenomena is possible, including their location and significance,

- Phase synchronization of the signal from many or one sensor improves the ability to separate individual phenomena,

- As presented on Figure 8, some phenomena which is visible on vibrations are not visible on microphone signal - in this case $16^{\text {th }}$ order also presented on figure $7 \mathrm{~d}$. This information is very important considering complex behaviour of car interior.

- Increasing the number of sensors can further increase the resolving power of the analysis and help identify reflections in an acoustic environment as complex as the interior of a car,

- Due to the high vibroacoustic coupling of the acoustic intensity / acoustic velocity of particles in the near field, it is possible to interfere with a specific panel of the vehicle interior (especially with an electric drive).

\section{ACKNOWLEDGEMENTS}

The work was created as part of research project of Department of Mechanics and Vibroacoustics no. 16.16.130.942 AGH in Kraków.

Special thanks to Weles Acoustics LLC for lending the WA301 probe.

Results presented in this paper were obtained thanks to the work carried out under the POIR.01.01.01-00-0339/17 project (financed by NCBR).

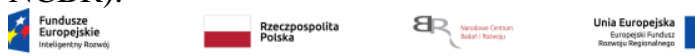




\section{REFERENCES}

1. Cao J, Liu J, Wang J, Lai X. Acoustic vector sensor: Reviews and future perspectives. IET Processing. 2017;11(1):1-9. https://doi.org/10.1049/iet-spr.2016.0111.

2. Comesana D. Scan-based sound visualisation methods using sound pressure and particle velocity. PhD Thesis, University of Southampton. 2014.

3. Comesana D, Tijs E, Kim D. Direct sound radiation testing on a mounted car engine. SAE Int. J. Passeng. Cars - Mech. Syst. 2014;7(3):1229-1235. https://doi.org/10.4271/2014-01-2088.

4. Comesana DF, Gonzalez D, Storani T, Meng F. Assessment of squeak and rattle noise of a car seat using 3d sound intensity measurements. SAE Technical Paper. No. 2020-01-1557.

5. Hald J. Patch holography in cabin environments using a two-layer hand-held array with an extended SONAH algorithm. Proceedings of Euronoise 2006.

6. Huang HB, Li RX, Yang ML, Lim TC, Ding WP. Evaluation of vehicle interior sound quality using a continuous restricted Boltzmann machine-based DBN. Mechanical Systems and Signal Processing. Part A. 2017;84:245-267. https://doi.org/10.1016/i.ymssp.2016.07.014

7. Jacobsen F, HE de Bree. A comparison of two different sound intensity measurement principles. The Journal of the Acoustical Society of America. 2005; 118(3):1510-1517. https://doi.org/10.1121/1.1984860.

8. Kłaczyński M. Identification of aircraft noise during acoustic monitoring by using 3D sound probes. Acta Physica Polonica A. 2014;125(4A):144-148. https://doi.org/10.12693/APhysPolA.125.A-144.

9. Kotus J, Czyżewski A, Kostek B. 3D acoustic field intensity probe design and measurements. Archives of Acoustics. 2016;41(4):701-711.

10. LMS. Transfer Path Analysis, the qualification and quantification of vibroacoustic transfer paths. LMS International, Application Notes, 2005.

11. Meyer A, Döbler D. Noise source localization within a car interior using 3D-microphone arrays. Proceedings of the BeBeC 2006, Berlin, Germany. 2006.

12. Singh S, Mohanty A. HVAC noise control using natural materials to improve vehicle interior sound quality. Applied Acoustics. 2018; 140:100-109. https://doi.org/10.1016/j.apacoust.2018.05.013.

13. Swart DJ, Bekker A, Bienert J. The subjective dimensions of sound quality of standard production electric vehicles. Applied Acoustics. 2018;129:354364. https://doi.org/10.1016/j.apacoust.2017.08.012.

14. Tijs E, H de Bree. Mapping 3D Sound Intensity Streamlines in a Car Interior. SAE Technical Paper 2009-01-2175, 2009, https://doi.org/10.4271/200901-2175.

15. Weyna S. Acoustic energy distribution of real sources, WNT, Warszawa, 2005. (in Polish).

16. Weyna S. Identification of reflection, diffraction and scattering effects in real acoustic flow fields. Archives of Acoustics. 2003; 28(3):191-203.
17. Xu Z, Xia X, Lai S, He Z. Improvement of interior sound quality for passenger car based on optimization of sound pressure distribution in low frequency, Applied Acoustics. 2018; 130:43-51. https://doi.org/10.1016/j.apacoust.2017.08.019.

\section{Received 2021-06-30}

Accepted 2021-03-23

Available online 2021-09-24

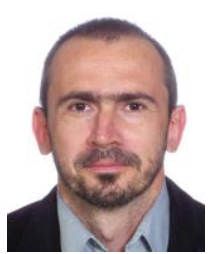

\begin{abstract}
Wojciech PALUCH M.S. Eng. is Experienced Noise and Vibration Engineer in NVH \& Modules Department at BWI Poland Technologies. He graduated from AGH University of Science and Technology in 2003 with Master of Engineering degree. He joined BWI in 2018. He has background in advanced vibroacoustic measurements, signal processing and problem solving methodologies. Responsible for development of new testing and analysis methods of shock absorber structure-borne noise. In 2019 he started doctoral studies at the Mechanical Engineering and Robotics Faculty at the AGH University of Science and Technology. He conduct researches in area of spatial sound propagation in car interior using novel 3D acoustic particle velocity sensor.
\end{abstract}

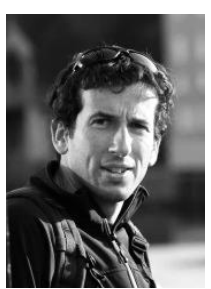

Maciej KŁACZYŃSKI Ph.D. D.Sc. Eng. Prof. AGH, works at Department of Mechanics and Vibroacoustics in AGH University of Science and Technology in Krakow. His research is focused on measurement, signal processing and pattern recognition methods of vibroacoustic signals applied in medicine, technology and environmental monitoring. Author of over one hundred scientific publications and conferences papers. Member of European Acoustics Association (EAA), Polish Acoustical Society (PTA) and Polish Society of Technical Diagnostics (PTDT). 